\title{
MAGEA1 wt Allele
}

National Cancer Institute

\section{Source}

National Cancer Institute. MAGEA1 wt Allele. NCI Thesaurus. Code C104510.

Human MAGEA1 wild-type allele is located in the vicinity of Xq28 and is approximately $6 \mathrm{~kb}$ in length. This allele, which encodes melanoma-associated antigen 1 protein, may be involved in embryonal development, tumor transformation, or tumor progression. 